\title{
The prize of peace (is eternal vigilance): a cautionary editorial essay on climate geopolitics
}

\section{Jon Barnett}

Received: 29 November 2007 / Accepted: 15 September 2008 / Published online: 12 May 2009

(C) Springer Science + Business Media B.V. 2009

Climate change researchers now influence thinking about world politics. There is no clearer recognition of this than the award of the 2007 Noble Peace Prize to the Intergovernmental Panel on Climate Change and to Al Gore J. for "their efforts to build up and disseminate greater knowledge about man-made climate change, and to lay the foundations for the measures that are needed to counteract such change". Yet power in world politics is an uncomfortable thing, and requires some critical reflection.

It will be asked, sooner or later, if the IPCC and Al Gore Jr, deserved the Nobel Prize, since it suggests most strongly that climate change research has advanced the common good. Likening them to past winners such as Médecins Sans Frontières, Amnesty International, and Martin Luther King is apposite: all have raised awareness of critical problems, all have advocated peaceful solutions, all can be said to have done much good, and little if any harm. There is no doubt that without the work of the climate researchers involved with the IPCC-their research and their advocacy-society would be blind to the danger that it faces.

However, the resulting growth in the awareness of the public and decision makers about the problem of climate change poses challenges to the guardians of the modern institutions that give rise to the problem and are threatened by its solutions. The strategy of OPEC and many energy intensive industries and oil companies in the United States, for example, has been to deny the need for change by questioning the science and highlighting the risks of responses. But there are other institutions at risk too, and principal among these are the security institutions whose ecological footprint makes them a key cause of climate change, and whose dependence on the discourse of an anarchic world without cooperation has always been a bulwark against the theory and praxis of a world where States

\footnotetext{
J. Barnett $(\bowtie)$

Department of Resource Management and Geography, The University of Melbourne, Melbourne, Victoria 3010, Australia e-mail: jbarn@unimelb.edu.au
} 
cooperate to achieve peace and security. Whereas OPEC and the US energy lobby respond through denial, the security institutions have far greater adaptive capacity.

The emergence of a new discourse on climate induced war suggests that not only is climate science influencing climate policy, its authority is being appropriated by the mainstream security policy community. A number of geopolitical visions of climate-induced wars have emerged in recent times. Almost all of them propose that climate change heightens the risk of violent conflict between countries, although a few are predominantly concerned with the risks climate change poses to human security (Brauch 2002; Smith and Vivekananda 2007; van Ireland et al. 1996). Some of these have been written by environmental scientists (e.g. Myers 1997; WGBU 2007), suggesting that the there may be some overstepping of the boundaries of scientific expertise for the sake of reaching diverse policy communities. Those that seem to have the greatest impact on policy discourse are written by those associated with the NATO security policy community (e.g. CSIS 2007; Schwartz and Randall 2003). The most dramatic and problematic of these is the report commissioned by the United States Department of Defense which argues that climate change could: "potentially destabilize the geopolitical environment, leading to skirmishes, battles, and even war due to resource constrains" (Schwartz and Randall 2003: 2).

The discourse on climate wars winds it way through the media too, with recent headlines such as "Climate change will cause new wars" (Canberra Times, June 22, 2007), "Climate change raises threat of water wars" (Japan Times, June 9, 2007), "Climate change will spur conflict" (South China Morning Post, November 22, 2007), and "Climate change can prompt mass migration and war" (Pretoria News, November 23, 2007). It has also worked its way into the United Nations security system, with the Security Council holding a debate on the impact of climate change on peace and security in April 2007. UN Secretary General Ban Ki Moon subsequently wrote that "the Darfur conflict began as an ecological crisis, arising at least in part from climate change" (Washington Times June 16 2007).

The discourse is influencing policy. For example, the Intelligence Authorization Act presented to Congress in October 2007 requires a "national intelligence estimate on global climate change", which includes assessing "the anticipated geopolitical effects of global climate change and the implications of such effects on the national security of the United States" and the "risks posed by global climate change, including increased conflict over resources or between ethnic groups, within countries or transnationally..". In September 2007 the US House of Representatives Investigations and Oversight Subcommittee of the House Committee on Science and Technology convened a hearing to examine the threats of climate change to national security, with the chairman Brad Miller saying that "the possibility of a world transformed by climate change is not a science fiction image of a post-apocalyptic society, it is not a road warrior movie, it is happening now".

It probably goes without saying, but there is some distance between the idea of peace as promoted by the Nobel Peace Prize and the national security interests of the United States Government. The latter spent US \$529 billion on defence in 2006, which was more than the next 14 biggest spenders combined, and accounted for $46 \%$ of world military spending that year (SIPRI 2007). Indeed, conservatively assuming average emissions per unit of GDP from the military sector (which would also exclude emissions arising from warfare), the US armed forces produced at least $1 \%$ of global greenhouse gas emissions in 2006. 
A major problem with the popular discourse on climate wars is that it is excessively general, and poorly if at all informed by evidence. In all cases the discussions are speculative, and ambiguous about what they mean by 'conflict' and where it will occur (Barnett 2003; Nordås and Gleditsch 2007). The vision is a large scale and blurred one. Yet these uncertainties and ambiguities are poorly recognised and are not dealt with in the systematic way that they are in the recent Working Group I report of the Fourth Assessment Report of the IPCC. Of course, social science is not science in the same way that Working Group I is, however, what is passing as research on climate conflicts is not good social science either: it eschews evidence, most of it ignores the large body of research on the causes of conflict generally and on so-called 'environmental conflicts' in particular, and very little of it is peer-reviewed.

Instead, like all discourses, the discourse on climate wars is better understood as an artefact of the will to power of those who make them and those who want to be close to power. In this case the power that lies behind the discourse is the western countries that are both militarily powerful and least vulnerable to environmental change (Barnett 2001; Dalby 2002). These countries require discourses of global disorder in order to justify their security and trade policies, and their security and defence agencies require problems to justify their continued existence in a world where the threat of war has diminished since the end of the cold war. They seem to be appropriating the dangers of climate change to serve these institutional agendas. That these agendas are inimical to a sustainable world where there are deep cuts in emissions and considerable action on adaptation is obvious. Albeit for the most part unwittingly, climate change research is now serving this contradictory agenda.

This appropriation of climate change research is possible in part because both climate models and the practical geopolitics of the mainstream security policy community deal in panoptic visions of the world. Climate modelling is panoptic in the sense that it offers a supposedly objective and total view of global space, communicated through powerful images and visualisation technologies such as satellite photos of ice sheets, aerial photographs of landscapes, and visualisations of sealevel encroachments. It is geopolitical in that this view of global space is one of large scale sequences of cause and effect. Yet whereas the idea of the panoptic in the work of Foucault (1977) and critical geopolitical theorists such as O'Tuathail (1996) also implies the impulse to master the surveilled space, this impulse is not evident in the work represented in Working Group I of the IPCC, although there is a danger that blanket policy solutions raised in Working Group III (such as global carbon markets) may justify crude interventions to control local places and peoples.

The panoptic gaze can never be an adequate basis for understanding and responding to the social world. The difference between the climate science represented in Working Group I and practical geopolitics is that whereas a physical science of the earthy system must be panoptic, recognises uncertainty, and is increasingly reaching out to include the kinds of nuanced insights into the heterogenous social impacts that the social sciences can provide, practical geopolitics depends on simple visions of a dangerous world. It is increasingly being recognised in climate change research-for example as reflected in chapter 17 of Working Group II of the IPCCC - that communities will respond to change in complex and diverse ways depending on their needs, values, cultures, capacities, institutional forms and environmental features. This diversity of social responses to change is consistently denied in practical geopolitical analysis. 
Indeed the idea of environmental change as a driver of conflict readily appeals to the mainstream security policy community because it fits with their biological understanding of the way people respond to scarcity. They see people as being like any other animal in that they respond to scarcity in only one way-by fighting (Barnett 2001). Not only does this naturalisation of the social world arguably misrepresent the behaviour of species in times of scarcity, it seriously misunderstands the way social systems respond to scarcity. Humans have cultures, which confer an ability to escape the constraints of environmental context that seem to afflict other species more directly, and which allow for the resolution of complex social problems in non-exclusive ways. Naturalising the social response denies the possibility of peace, justifies preparations for war, and, as has recently been argued in the debate about Darfur as an example of a climate conflict, excuses those people who make decisions to murder, rape, maim and torture (Abraham 2007; Hulme 2007).

None of this popular geopolitical discourse on climate wars is sensible, and there is little evidence to support it from over a decade of research into environmental violence (e.g. Barnett 2003; Buhaug et al. 2008; Peluso and Watts 2001). In order to establish if climate change may increase the risk of violent conflict in any given location, a complete assessment that identifies all the likely outcomes of climate change, accounting for exposure to risk, susceptibility to damage, adaptation and its limits and barriers, is first needed. It then needs to be established if those outcomes are ones that are likely to increase the risk of violent conflict, and this assessment can be informed by what is understood about the causes of violent conflict, and in particular the ways in which environmental changes affect the risk of violent conflict. However, the evidence about the links between environmental change and violent conflict is inconclusive. Neither qualitative examination of cases, nor work seeking to find generalizable findings based on statistical data, have produced robust findings (Buhaug et al. 2008).

Nevertheless, the magnitude of environmental changes expected to result from even $2^{\circ}$ of warming above pre-industrial levels (let alone higher rates of warming) may cause significant negative social outcomes in certain social systems - in particular low income and resource dependent societies. There is some evidence that some of the likely outcomes, such dwindling resource stocks, livelihood decline, decreasing state revenues, and increasing inequality across space and between classes, may create opportunities for opportunistic elites to harness resentment to mobilise people to fight, and this is more likely in states where regimes are weakened by decreasing revenues from resource based rents or taxes (Buhaug et al. 2008; Barnett and Adger 2007; Kahl 2006). If climate change causes migration, this too may be a cause of violent conflict in certain circumstances (Baechler 1999; Gleditsch et al. 2007; Reuveny 2007).

There is some more recent social science research that points to some potential ways in which certain aspects of climate may influence the likelihood of violent conflict. Miguel and others (2004) use rainfall variation as an instrumental variable for economic growth in 41 African countries and find that decreases in rainfall strongly increase the likelihood of conflict in the following year. Hendrix and Glaser (2007) and Meier et al. (2007) also find associations between rainfall variability and violent conflict. Nel and Ringharts (2008) show that rapid onset natural disasters related to climate and geology increase the risk of violent civil conflict, particularly in low and middle income countries. All of these studies use aggregated data sets, 
and are not without their empirical and methodological problems (see Buhaug et al. 2008), yet they do tentatively indicate the possibility of climate change increasing the risk of violent conflict under particular circumstances. There is a large difference, however, between increased risk, and predictions of future wars due to climate change. In none of these studies is there a suggestion that there are no solutions to reducing the risk of conflict arising from climate change, and there are indeed many possibilities for further minimising the risk of future conflicts even in the face of climate change (Carius et al. 2008).

The 2007 Nobel Prize has put peace on the agenda of climate science. At the same time heightened awareness about the dangers of climate change has resulted in a new discourse on climate wars which sustains some of the institutions at the heart of the problem, and which work more towards the cause of war than of peace. This discourse on climate conflicts might be less legitimate and tenable if climate change research did not actively or tacitly support it, were instead more critically engaged with it, and sought to advance understanding through rigorous, applied and critically aware social science.

Acknowledgements Many thanks to Neil Adger, Simon Dalby, and Mike Hulme for their helpful comments on an earlier version of this essay. This work was prepared with the assistance of Australian research Council Discovery Project DP0556977.

\section{References}

Abraham C (2007) In the heat of the moment. New Sci 196(2626):24

Baechler G (1999) Violence through environmental discrimination: causes, Rwanda arena and conflict model. Kluwer, Dordrecht

Barnett J (2001) The meaning of environmental security. Zed Books, London

Barnett J (2003) Security and climate change. Glob Environ Change 13(1):7-17

Barnett J, Adger N (2007) Climate change, human security and violent conflict. Polit Geogr 26(6): $639-655$

Brauch H (2002) Climate change, environmental stress and conflict. In: Federal Ministry for the Environment, Nature Conservation and Nuclear Safety (ed) Climate change and conflict. Can climate change impacts increase conflict potentials? What is the relevance of this issue for the international process on climate change? Federal Ministry for the Environment, Nature Conservation and Nuclear Safety, Berlin, pp 9-112

Buhaug H, Gleditsch N, Theisen O (2008) Implications of climate change for armed conflict. Paper presented at the World Bank Workshop on the Social Dimensions of Climate Change, The World Bank, Washington, 5-6 March 2008

Carius A, Tanzler D, Maas A (2008) Climate change and security: challenges for German development cooperation. Deutsche Gesellschaft fur Technische Zusammenarbeit (GTZ), Eschborn

CSIS (Centre for Strategic and International Studies) (2007) The age of consequences: the foreign policy and national security implications of global climate change. CSIS, Washington, DC

Dalby S (2002) Environmental security. University of Minnesota Press, Minneapolis

Foucault M (1977) Discipline and punish: the birth of the prison. Pantheon Books, New York

Gleditsch N, Nordas R, Salehyan I (2007) Climate change and conflict: the migration link. International peace academy coping with crisis working paper. International Peace Academy, New York

Hendrix C, Glaser S (2007) Trends and triggers: climate, climate change and civil conflict in subSaharan Africa. Polit Geogr 26(6):695-715

Hulme M (2007) Climate conflict. New Sci 196(2629):26

Kahl C (2006) States, scarcity, and civil strife in the developing world. Princeton University Press, Princeton 
Meier P, Bond D, Bond J (2007) Environmental influence on pastoral conflict in the horn of Africa. Polit Geogr 26(6):716-735

Miguel E, Satyanath S, Sergenti E (2004) Economic shocks and civil conflict: an instrumental variables approach. J Polit Econ 112(4):725-753

Myers N (1997) Environmental refugees. Popul Environ 19(2):167-182

Nel E, Ringharts M (2008) Natural disasters and the risk of violent civil conflict. Int Stud Q 52(1): 159-185

Nordås R, Gleditsch N (2007) Climate conflict: common sense or nonsense? Polit Geogr 26(6): $627-638$

O’Tuathail G (1996) Critical geopolitics. Routledge, London

Peluso N, Watts M (eds) (2001) Violent environments. Cornell University Press, Ithaca, NY

Reuveny R (2007) Climate change induced migration and violent conflict. Polit Geogr 26(6):656-673

Schwartz P, Randall D (2003) An abrupt climate change scenario and its implications for United States national security. Global Business Network, San Francisco. http://www.gbn.com/ ArticleDisplayServlet.srv?aid=26231. Cited 8 April 2007

SIPRI (Stockholm International Peace Research Institute) (2007) SIPRI yearbook 2007: armaments, disarmament and international security. SIPRI, Stockholm

Smith D, Vivekananda J (2007) A climate of conflict: the links between climate change, peace and war. International Alert, London

van Ireland E, Klaassen M, Nierop T, van der Wusten H (1996) Climate change: socio-economic impacts and violent conflict. Report No. 410200 006. Dutch National Research Programme on Global Air Pollution and Climate Change, Wageningen

WGBU (German Advisory Council on Global Change) (2007) World in transition: climate change as a security risk. Summary for policy makers. WBGU, Berlin. http://www.wbgu.de/ wbgu_jg2007_engl.html. Cited 29 November 2007 